\title{
SOME RETARDED GRONWALL TYPE INTEGRAL INEQUALITY AND ITS APPLICATIONS
}

\author{
YOUNG-Ho KIM AND TH. M. RASSIAS
}

\begin{abstract}
We consider nonlinear integral inequalities of Gronwall type for functions of one variable or two variables. We also study integral inequalities for proving the boundedness and uniqueness of the solutions to hyperbolic partial differential equations.
\end{abstract} equations.

Mathematics subject classification (2000): 26D15, 35A05.

Key words and phrases: Bernoulli's inequality, Gronwall-type integral inequality, partial differential

\section{REFERENCES}

[1] D. BAINov AND P. SimeOnov, Integral Inequalities and Applications, Kluwer Academic Publishers, Dordrecht, 1992.

[2] E.F. BeCKenBaCh AND R. Bellman, Inequalities, Springer-Verlag, New York, 1961.

[3] R. Bellman, The stability of solutions of linear differential equations, Duke Math. J. 10 (1943), 643-647.

[4] I. BIHARI, A generalization of a lemma of Bellman and its application to uniqueness problems of differential equations, Acta Math. Acad. Sci. Hungar. 7 (1956), 71-94.

[5] S.S. DRAGOMIR, On Gronwall type lemmas and applications, "Monografii Matematics" Univ. Timişoara No. 29 (1987).

[6] S.S. DRAGOMIR AND N.M. IONESCU, On nonlinear integral inequalities in two independent variables, Studia Univ. Babeş-Bolyai, Math. 34 (1989), 11-17.

[7] T.H. GRONWALL, Note on the derivatives with respect to a parameter of solutions of a system of differential equations, Ann. Math. 20 (1919), 292-296.

[8] O. Lipovan, A retarded Gronwall-like inequality and its applications, J. Math. Anal. Appl. 252 (2000), 389-401.

[9] M. MEDVED, Nonlinear singular integral inequalities for functions in two and $n$ independent variables, J. Inequalities and Appls. 5 (2000), 287-308.

[10] D.S. Mitrinović, J.E. PeČARIĆ AND A.M. FinK, Classical and new Inequalities in Analysis, Kluwer Academic Publishers, Dordrecht, 1993.

[11] B.G. PachPatTE, Explicit bounds on certain integral inequalities, J. Math. Anal. Appl. 267 (2002), 48-61. 